\title{
The Death of Samson
}

\section{ShaUl Bar (UNIVERSity OF MEMPhIS, USA)}

\begin{abstract}
This article examines the story of Samson's death. From the time that he was captured by the Philistines until his death, the Bible describes at length the events that led to his downfall. This includes three major parts. The first Philistine event was jubilation at the temple of their god Dagon, which consists of two short rhymes which appear in poetic form. This was followed by Samson's plea for God's help and the destruction of the Philistine's temple. The last part mentions Samson's burial. Examination of the Philistine's rhymes reveals that they ascribe Samson's downfall to their god, which adds a religious dimension to the story. Samson was the only person whose death wish was granted. His death wish is similar to other death wishes from the ancient world. The mention of his burial and its location links the end of the story to its beginning, which is the story of his birth.
\end{abstract}

KEYWORDS: Samson, Philistines, seranim, Dagon, Fable, En-hakkore

\section{A INTRODUCTION}

Samson was a unique judge, unlike any other mentioned in the Book of Judges. Thus, not surprisingly, even his death was described in exceptional detail. The last part of Samson's life is narrated in chapter 16:23-31. This section can be divided into three parts: 1) Verses 23-27 that describe the Philistine's jubilation at Samson's fall; 2) Verses 28-30 Samson's revenge and his death; 3) Verse 31 the burial of Samson with a 'formula ending'. Hence, in the current paper we examine each of these segments. We will study the Philistines' jubilation, which included two short rhymes, one by the seranim and the second by the people. The rhyme by the seranim was partially repeated by the people. So, what do the rhymes try to convey and how do they differ? In the second part, we describe Samson's revenge which is preceded by a prayer to God. Therefore, we compare it to his first prayer to God at Ramath-lehi and see how different the prayers are. In his prayer, Samson expressed a death wish; therefore, we judge it against other death wishes and their outcome. Samson's desire to die was compared to some of the fables from ancient times, in particular the fable of the wasp and the snake, and the tuna fish who was being chased by a dolphin. The similarities of these fables are compared to Samson's death wish. Finally, we describe Samson's burial and the special language that was used to describe it. Was there any

Submitted: 21/06/2019; peer-reviewed: 31/07/2019; accepted: 28/02/2020. Shaul Bar, "The Death of Samson", Old Testament Essays 33 no. 1 (2020): 162 - 174. DOI: https://doi.org/10.17159/2312-3621/2020/v33n1a10. 
significance to his burial site? In addition, why does the narrator mention for a second time that Samson judged Israel for 20 years? In this essay, our main goal is to rediscover the last part of Samson's life. In order to achieve this goal, we will use a synchronic method analysing Chapter 16, as it stands. Material found in the Talmud, the Midrashim, and Jewish medieval commentators will be reviewed. Everything that Jews thought for more than a thousand years can be found there. Though the interpretive methods of the mediaeval commentators vary, we still can find that they compromise between the literal and the Midrashic. Additionally, modern commentators who pursue philological contextual interpretations with a logical and scientific perspective will be analysed. This, in turn will shed more light on the persona of Samson.

\section{B THE PHILISTINE'S JUBILATION}

Samson was brought down to Gaza where he became a mill slave in prison. He was performing tasks that were normally done by animals; this was to humiliate him. It has been suggested that the image of grinding is a euphemism for sexual intercourse (Job 31:10; Isa 47:2-3). The defeated enemy performed sexually for the winners. ${ }^{1}$ Indeed, in the Talmud we read: "R. Johanan said: Grind means nothing else than [sexual] transgression; and thus, it is stated, then let my wife grind unto another. It teaches that everyone brought his wife to him to the prison that she might bear a child by him [who would be as strong as he was]". ${ }^{2}$ It is noteworthy to add that to work like an animal milling grain was a task that was given to prisoners of war (Jer 52:11). ${ }^{3}$ Moore points to customs from Greek and Roman civilizations: "Among the Greeks and Romans, being put to work at the mill was a not uncommon and much-dreaded punishment of slaves, to which there are many references in comic poets. Freeman were also punished in this way for slight offences."4 According to Bartusch, by Samson being shaved, bound, imprisoned at the mill stone and blinded by these actions the Philistines stripped Samson of his honour..$^{5}$ More so, it was pointed out that: Honour is displayed when the head is crowned, anointed, touched, or covered. Dishonour, however, is symbolized when the head is uncovered or made bare by shaving and when it is cut off, struck, or slapped." To celebrate their victory over

1 Susan Niditch, Judges: A Commentary (Louisville: Westminster John Knox, 2008), 171.

2 Soțah 10a.

3 For Mesopotamian practice see: Van der Toorn, "Judges xvi 21 in the Light of Akkadian Sources," VT 36(1986):248-53.

4 G.F. Moore, A Critical and Exegetical Commentary on Judges (New York: Charles Scribner's sons, 1895), 357.

$5 \quad$ Mark W. Bartusch, Understanding Dan (JSOT 379; Sheffield: Sheffield Academic Press, 2003), 160.

6 Bruce J. Malina and Jerome H. Neyrey, "Honor and Shame in Luke-Acts: Pivotal Values of the Mediterranean World," in The Social World of Luke -Acts, edited by Jerome H. Neyrey (Peabody, Mass: Hendrickson,1991), p.35. 
Samson, the Philistines made a great sacrifice to their god, Dagon. They praised him for delivering Samson into their hands. When their hearts were merry from eating and drinking, they called for Samson to come out of the prison house so that he would entertain them. They amused themselves watching him suffer. This is the background of the last encounter between Samson and the Philistines. It takes place in the palace of Dagon the Philistine god. A new dimension is added to our story: a feud between Samson's God and the Philistine god (Judg16:2324). This motif would be repeated later in the Book of Samuel, which describes the battle between Israel and the Philistines.

Before describing the Philistine's jubilation, the narrator starts with a report that Samson's hair started to grow, which hints at the rejuvenation of Samson's power. Hair cutting and shaving indicate "transformation" in the Hebrew Bible. Samson's loss of hair points to a critical juncture in his life as does its regrowth. ${ }^{7}$ In spite of the hair growth, the author later stressed the fact that Samson turned to God in prayer (v.28). Turning to God in prayer is similar to the previous episode at En-hakkore of Lehi, where Samson turned to God in prayer (Judg 15:18). So why does the author mention the hair? It appears that by mentioning the hair, the author had two objectives in mind; firstly, he connected our section with the segment of Samson and Delilah and the birth narrative. And secondly, he diminished the magical nature of the hair and instead showed the superiority of prayer. ${ }^{8}$

It was through his prayer that Samson achieved his last victory against the Philistines. The prayer shows his dependence on God. More so, it appears that Samson was aware of his faith. He turned to God to remember him and to give him strength for the last time. This is in contrast to the episode of En-hakkore of Lehi, where the prayer was in the form of complaints and resentment. Here, he asks for God's mercy. By God answering Samson's prayer, the narrator shows that his powers were derived from God and he was a tool in the hands of providence. Exum pointed to the importance of prayers in the Samson stories. God's intervention in response to prayer appears in each of the major parts of the story. The birth account (13); cycle one chapters 14-15 and cycle 2 chapter 16. According to her, prayers serve two purposes: to reveal dependence on Yahweh and Yahweh's openness to human supplication and therefore the acceptance of humans as agents to fulfil the divine plan. ${ }^{9}$

The Philistines celebrated their victory at the temple of their deity Dagon. Temples that are dedicated to the god Dagon existed at Gaza, Ashdod and Beth-

7 Saul Olyan, "What Do Shaving Rites Accomplish and What Do They Signal in Biblical Ritual Contexts?” JBL 117(1998):611-22.

8 Yairah Amit, The Book of Judges: The Art of Editing. Translated by Jonathan Chipman (Leiden: Brill, 1999), 305-06.

9 J. Cheryl Exum, "Theological Dimension of the Samson Saga," VT 33(1983):45. 
Shean (Judg 16:23; 1 Sam 5:1-7; 1 Chr 10:10). ${ }^{10}$ Dagon was an important and widely worshipped deity in the Ancient Near East. ${ }^{11}$ The Philistines adopted Dagon as their god after their settlement in Canaan. The fact that Samson was brought to the temple of Dagon, the god of grain, is ironic since Samson burned the grain and the fields of the Philistines. By bringing him to their temple, the Philistines ascribe Samson's downfall to their god not to the Almighty. It's noteworthy that in the Hebrew Bible there is a current motif that describes an Israelite in the dungeon. Following the incarceration, the Israelite is elevated in status. This was the case with Joseph (Gen 41) and Daniel (1-6). In the Samson story the reverse is true; Samson is led from the dungeon to his death. rhythm:

The Philistines expressed their jubilation by chanting a short-repeated

"Our god has delivered into our hands

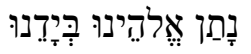

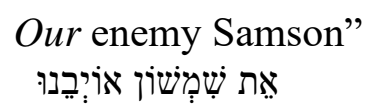

This short rhyme was chanted by the seranim. Their gathering was accompanied by a great sacrifice to their god Dagon. The Philistines did not turn to the aid of their god Dagon. However, since they captured Samson, they attributed their success to their god. By mentioning their god, they added a religious dimension to the story. Samson is not only the enemy of the Philistines; he is also the enemy of their god. The verses stress the religious contest between the Israelites and the Philistines with the mention of their god Dagon. ${ }^{12}$ The belief that their god is behind their victory is not limited to the Philistines. Indeed, we find that the Israelites also attributed their victories to their God: "So the Lord our God also delivered into our power King Og of Bashan, with all his men, and we dealt them such a blow that no survivor was left" (Deut. 3:3). When the spies return from Jericho they said: "The Lord has delivered the whole land into our power; in fact, all the inhabitants of the land are quaking before us" (Josh. 2:24).

The word our is a key word in verse 23 and it is repeated three times: Our god has delivered into our hands, our enemy Samson. The fact that it is repeated here three times, as well as three times in the next verse, (v.24) strengthens the

\footnotetext{
10 According to the Book of Maccabees the temple in Ashdod was destroyed by the Hasmonean Jonathan (1Mac 10:83-4).

11 In the Hebrew Bible Dagon is always associated with the Philistines (1Sam. 5:2-5, 7: 1Chr. 10:10). See: J.F. Healy, "Dagon," $D D D, 216-19$; L. K. Handy, "Dagon” $A B D$, 2:1-3.

12 Niditch, Judges: A Commentary, 171.
} 
perception that this was a rhyme that was chanted and sang. ${ }^{13}$ The Philistines appear here as a chorus. This form of singing by a large group of people was also prevalent among the Israelites. When God delivered the Israelites from the Egyptians and the Israelites crossed the sea, Moses and the Israelites sang to the Lord (Exod. 15). When God gave the Israelites water, they sang a song at the well (Num. 21:17). Following David's victory over Goliath, the women sang: "Saul has slain his thousands; David, his tens of thousands" (1Sam.18:7; 21:12; 29:5).

After the rhyme that the seranim chanted, we find a second rhyme that the people chanted. The sight of Samson caused major jubilation. Samson is not only the enemy of the seranim, he is also the enemy of all Philistine people. Hence, they chanted:

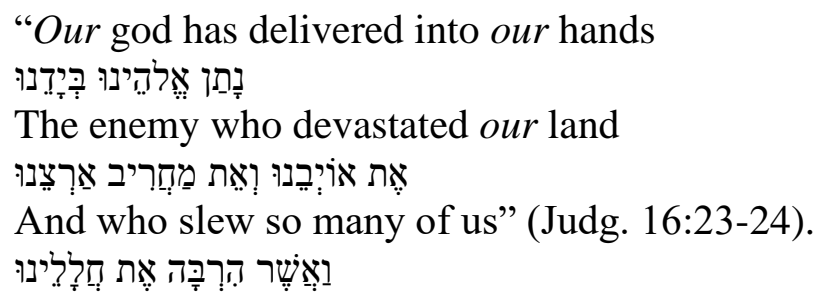

This rhyme is longer than the rhyme chanted by the seranim. As a matter of fact, the first rhyme was an abbreviated form and the second one is the expansion. Hence, the people repeated the rhyme chanted by the seranim, "Our god has delivered into our hands." These are the same words that were chanted by the seranim but with one slight change, instead of the last part "Our enemy Samson" they changed the words to "the enemy." This kind of change is typical in biblical poetry (Num.23:20; Judg. 5:27; 2Sam.1:20b). But more importantly, while the seranim only state that Samson was their enemy, here the people elaborate and describe the destruction that was caused by Samson. In their rhyme, the Philistines accused Samson of two crimes: he ruined their land and caused many deaths. This refers to the story about the foxes and the story of the ass's jaw. Why didn't the seranim mention those events? We believe that it was too painful for them to admit their failure, they were devastatingly humiliated by Samson, and therefore, they stressed only the triumph over Samson. Noteworthy here is how the Philistines ended their rhyme in the past tense, "who slew so many of us." In other words, they were certain and confident that Samson would not be able to kill them anymore. However, this was wishful thinking since Samson would kill many of them later.

The Philistines brought Samson to amuse themselves (v.25). It appears that this verse should be placed before verse 24 since in that verse we read "when

13 According to Kim: "The rich end rhyme (our) heightens the effect of the song as a chant or chorus." See: Jichan Kim. The Structure of the Samson Cycle (Kampen-The Netherlands: Kok Pharos Publishing House, 1993), 359. 
the people saw him." In other words, they could not see him before he was

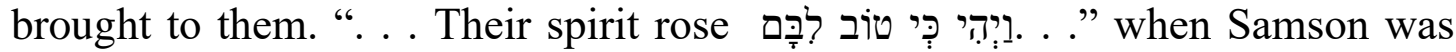
brought to their palace, this expression refers to drinking wine, which appears on other occasions in the Hebrew Bible. ${ }^{14}$ The call to bring Samson for entertainment has some similarities to King Ahasuerus story. According to the story, the king was merry with wine, he ordered Queen Vashti to come forth to display her beauty (Esth. 1:10-11). In both stories the drinking resulted in bad judgment. $^{15}$

The sight of their enemy faltering and fumbling caused the Philistines to break out in great laughter. To describe Samson entertaining his audience, the

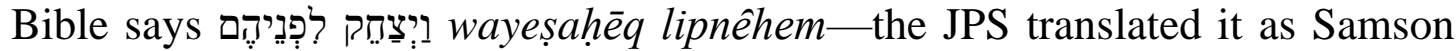
was dancing for the Philistines. ${ }^{16}$ It was suggested that sexual connotations (Gen. 26:8; 2 Sam 6:5, 21-2; 1 Chron 15:29); but here the laughter is vindictive. ${ }^{17}$ All along, the Philistines wanted to make Samson helpless (Judg 16:5, 6, 19) and they achieved it. They humiliated Samson by bringing him to the palace of their god Dagon. This recalls a similar situation with King Saul. After the last battle at Mount Gilboa when Saul and his sons died, the Philistines stripped him and carried off his head and his armour. They placed his armour in the temple of their god and they impaled his head in the temple of Dagon (1 Chron 10:10).

There was a pause in the entertainment that Samson provided to the Philistines. Hence, the narrator describes to us that the Philistines put Samson between the pillars at the centre of the building. Why they did so is not clear. It is possible that they stationed him at the centre of the temple so people would have a good view of Samson. The Excavation at Tell Qasile shows remains of a temple in Stratum X. Two pillars supporting the roof were integral parts of the temple construction they were three metres apart set on the ground stone bases. ${ }^{18}$ The mention of the pillars here is foreshadowing the future. It is also a reminder to the reader of Samson's previous heroic deeds, where pillars also played a role when he carried the gates of Gaza. By describing Samson carrying the gates, the narrator reinforced the image of Samson that appeared in chapters 14-15. Samson is described as having larger than life strength which will be displayed when he would topple the temple. According to Mobley: "it serves as a dress rehearsal for the conclusion of the entire saga: here in Gaza, Samson topples a structure, the city gate. He will do so again." 19

\footnotetext{
142 Sam 13:28; Esth 1:10.

15 Yair Zakovitz, The Life of Samson (Jerusalem: Magnes, 1982), 199.

16 The same expression is used with David as he was "dancing before Yahweh" (2Sam 6:21).

17 Niditch, Judges: A Commentary,167.

18 A, Mazar, "A Philistine Temple at Tell Qasile," BA 36(1973):42-48.

19 Gregory Mobley, The Empty Man (New York: Doubleday, 2005), 190-91.
} 
Because Samson was blind, he had an escort who held him by his hand. Samson asked him to lead him so he could feel the pillars the temple rested on. In the previous verse (v.25), the pillars were already mentioned, but here the narrator says these were the pillars that the temple rested on. This detail is significant for a person who wants to topple the pillars of the temple and not to lean on them. Samson is portrayed here as helpless; he is blind and needs help. This is in contrast to his past when all along he fought his battles with no aid. Nevertheless, Samson who had been passive so far and did as he was told by the Philistines, then took the initiative. He ordered the boy who was leading him to guide him, so he could feel the pillars in order to lean on them. The boy who guided Samson is a secondary character and his role is limited exclusively to this verse-he neither appears before nor after. ${ }^{20}$ According to Josephus, Samson concealed from the boy his true purpose, hence he says: "And he, deeming it direr than all his ills to be unable to avenge of such insults, induced the boy who led him by the hand - telling him that from weariness he needed a stay whereon to rest - to conduct him close to the columns." ${ }^{21}$ It's noteworthy that Josephus omits the words "the pillars that the temple rests upon"; again this was done in order to conceal his true plan from the boy.

Meanwhile, there is a pause by the narrator. He describes a packed temple with men and women and the Philistine seranim in attendance. In addition, there were 3,000 people on the roof, all of them were watching Samson dance. So far, we read in verses 23, 24, 27 about the Philistine's deeds, and in verses 25-26 about Samson's actions. Now the narrator breaks from his pattern and describes the temple and the celebration that is taking place. This is done in order to increase the tension and the magnitude of Samson's act. According to our verse, not only was the temple full of men and woman, additionally there were 3,000 people on the roof. As we previously mentioned, the numbers of Samson's enemies increased from episode to episode. Since, 3,000 refers only to the people on the roof, the sage's exaggerated, and "R. Levi said: It is written, And there were upon the roof about three thousand men and women (v.27). These were the number on the edge of the roof, but no one knows how many were behind them." 22

\section{SAMSON'S REVENGE}

Samson's revenge and his death are described in verses 28-30. Samson uttered a short prayer to God. He pleaded for God's help for one last display of strength that would help him take vengeance against the Philistines. In contrast to his first prayer to God at Ramath-lehi, where he referred to God by the pronoun You

20 Zakovitz, Life of Samson, 201.

21 Josephus, Flavius. Jewish Antiquities, translated by H. St. J. Thackery (Cambridge, MA: Harvard University Press,1930),5.315.

22 Gen. R. 98:14. 
(Jud15:18), here in his second prayer to God, Samson uttered the divine name twice, O Lord God. This divine title is rarely used in the Torah (Gen 15:2, 8; Deut. $3: 24$; 9:26). It is used in a context of complaint prayer and request. He asked God to remember him for the personal wrong he was suffering. In his plea

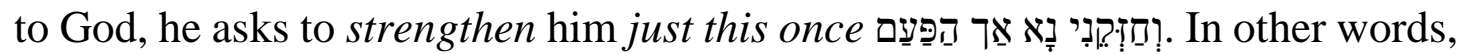

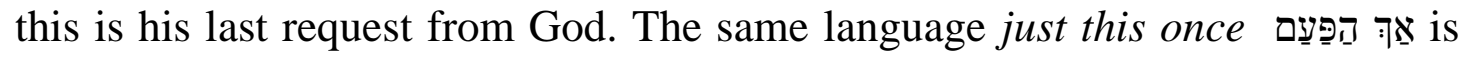
also found in Abraham's plea on behalf of the people of Sodom and Gomorrah after several attempts to persuade God (Gen 18:32); as well as for Gideon when he requests a sign for a second time from God (Judg. 6:39). Like Abraham and Gideon's pleas, Samson also appeals to precedent. God has strengthened him in the past, now he asks him for the last time, and he would not trouble God anymore. Furthermore, he asks God to remember him. The motif of remembrance is recurring many times in the Hebrew Bible. It implies faithfulness to the covenant between God and his people. Samson is calling on God to act based on the special relationship he has with God as he has been a Nazirite of God even before he was born.

Since Samson's eyes were gouged, he asks for revenge on the Philistines: "if only for one of my two eyes." (16:28). In other words, the death of the Philistines would atone for the cruelty exacted upon him. Not clear, however, is why Samson mentioned only one eye. Why didn't he ask for revenge for the loss of two eyes? We find an answer in the Midrash:

"R. Aha answered: He begged from Him: 'Sovereign of the Universe! Grant me reward for my loss of one eye in this world and let the reward for my loss of the other one be kept ready for me in the hereafter." 23

The narrator does not tell the reader that God hearkened to Samson's prayer, but his actions show that his prayer was answered. Samson grasped the two main pillars that supported the roof, and then bending forward, he forced them out of the perpendicular. Feeling that he had regained his strength he said: "let me die with the Philistines" (v. 30). This is not a request, but it is a cheering cry that resulted in the death of thousands of Philistines. Ironically, blind, chained, and ridiculed, as he died, Samson killed more Philistines than in his entire life before, ending his life in a dramatic fashion. Usually people achieve more during their lifetime, but with Samson we find the reverse. The measure of Samson's success is the number of casualties he inflicted on the Philistines. Samson dies according to his own wish. Samson's desire to die has been compared to some of the fables from ancient times, in particular, the fable of the wasp and the snake.

"A WASP seated himself upon the head of a Snake and, striking him unceasingly with his stings, wounded him to death. The Snake, being in great torment and not knowing how to rid himself of his 
enemy, saw a wagon heavily laden with wood, and went and purposely placed his head under the wheels, saying, "At least my enemy and I shall perish together." 24

In another fable we read:

"A tuna fish who was being chased by a dolphin was splashing madly through the water. Just when the dolphin was about to catch him, the tuna fish heaved himself forward with a great effort and landed on an island. Matching his effort, the dolphin ran aground beside him. The tuna fish then turned to look at the gasping dolphin and said, 'I do not grieve over my own death, so long as I am able to see that the one to blame is dying together with me!'

The fable shows that people readily undergo a disaster when they can witness the destruction of those who are to blame. ${ }^{25}$

In his first prayer to God, Samson asked for his life and he was revived (Judg 15:18). By contrast, his second prayer asked for his death and his wish was granted. This is the only time in the Hebrew Bible that such a wish was granted. The Bible mentions other heroes who implored God to end their lives. We read about Moses (Num11:10-15), Elijah (1 Kgs 19:4), Jeremiah (20:17), and Jonah. ${ }^{26}$ However, God refused these heroes' requests and they continued with their mission. ${ }^{27}$

According to the Gemara, the reason for Samson's harsh punishment is because "Samson rebelled [against God] through his eyes as it said, And Samson said unto his father, Get her for me, because she is pleasing in my eyes; therefore the Philistines put out his eyes, as it said, and the Philistines laid hold on him and put out his eyes." 28 It is noteworthy that when David is chosen to be the King of Israel, God said to Samuel: "For not as man sees [does the Lord see]; a man sees only what is visible, but the Lord sees into the heart" (1 Sam 16:7). In other words, God can see all, but man's vision is limited. Ironically, as long as Samson could see, he was "blind" to his own deeds; it was only when the Philistines put out his eyes that he became aware of his weakness. Still, the sages tried to balance the harsh verdict that Samson received by saying: "Rav said: Samson said before the Holy One Blessed is He: Master of the Universe! Remember for me the twenty two years that I judged Israel and I did not even say to them, 'Bring a staff for me from one place to another place." 29 It was noted that this Midrash is

24 Laura Gibbs, translator, Aesop's fable: New Translation (Oxford: Oxford University Press, 2008), no.161, p.83.

25 Aesop's Fables, no.160, p.83

26 Edward L, Greenstein, "Riddle of Samson," Proof 1(1981): 242.

27 D.T, Olson, "Judges," In NIB 2:860. Nashville: Abingdon, 1988.

28 Soțah. $9 b$.

29 Ibid., 10a. 
similar to Samuel's speech: "Whose ox have I taken, or whose ass have I taken? Taken a bribe to look the other way." (1Sam 12: 3). ${ }^{30}$

Samson says further, as recorded in the Gemarah, that he had been careful not to accept bribes. Therefore, the loss of the eyes could not be attributed to bribery "which blinds the eyes of the wise" (Deut 16:19). More so, the Midrash praises Samson for acting alone in his wars and not using his people.

\section{THE BURIAL OF SAMSON}

The narrator ends the last part our story by mentioning that his brothers and his entire father's house came to pick up his body. This is the first time that we hear that he had brothers. It shows that they respected their brother. Abravanel (Don Isaac Abravanel, 1437 - 1508) pointed out that Samson's mother was barren, but after she bore Samson, she also had other sons, as in the case of Hannah the mother of Samuel (1 Sam 2:21). Alternatively, mentioning brothers refers to Samson's family. As for his father's household, this refers to the rest of his father's tribe.

The verse that ends the Samsonite cycle brings us back to the beginning, the story of his birth. ${ }^{31}$ As Samson was passive in his birth, so he is after his death. His family members are acting here and burying him. The description of carrying Samson and bringing him to his burial site is reminiscent of the burial of Jacob: "all of Joseph's household, his brothers, and his father's household... His sons carried him to the land of Canaan and buried him in the cave of the field of Machpelah, and the field near Mamre, which Abraham had bought for burial site from Ephron the Hittite." (Gen 50:8,13). ${ }^{32}$

The family buried Samson between Zorah and Eshtaol at the tomb of his father Manoah. Hence, signalling reconciliation between the family and Samson. ${ }^{33}$ By declaring the site of his burial, the story returns to the opening stage of our story. There it says that the spirit of God seized Samson between Zorah and Eshtaol (13:25). As in the Samsonite story, an identical site for his election and burial appears also in the Gideon story. Gideon and Samson were elected and died at the same site. Hence, Gideon was elected at Oprah of the Abiezrites, the place where he was later buried in the grave of his father Joash (Jud. $6: 11 ; 8: 31)$. By mentioning Zorah and Esthol, the editor not only integrated the introduction to the rest of Samson story but also into the following story (18: 2,8,

\footnotetext{
30 Shamai Glendar "Samson is upon you," BethM 51(2006): 71.

31 Zakovitz, Life of Samson, 209.

32 Ibid.

33 Barry G. Webb, The Book of Judges (Grand Rapids, Michigan: William B. Eerdmans, 2012), 415.
} 
11). Brettler suggests that: "13:25 was written after 13-16, and perhaps even 1318 , had come together." "34 All of this came to tie the different chapters together.

There is a final note that says that he judged Israel for 20 years. A similar statement had appeared already at the end of chapter 15:20. According to Abravanel, the statement in chapter 15 refers to Samson's spiritual demise, which began at that point, but when mentioned in our chapter, it refers to his physical death (16:31). A similar interpretation is given by Radak (Rabbi David ben Joseph Kimhi, 11600 - 1235) who says that Samson's tenure lasted for 20 years. It was first mentioned after his exploit at En-hakkore because it was there that his downfall began. Until that time, he had enjoyed God's help, but from that point on, he began to stray from temptations and his end was a matter of time. We should point out that repetition was one of the tools that was used by the Biblical narrator. The repetition had several functions among them to show the difference between the different parts of the story. Hence, the statement in chapter 15 refers to Samson's spiritual demise, which began at that point, while the mention in our chapter refers to his physical death. Noteworthy is that the sages believed that Samson's judgeship lasted far after his death. According to them, his frightening memory held the Philistines in check for another 20 years. ${ }^{35}$ The Bible says at the end of the other judges' lives "that the land was tranquil for forty years," not so with Samson because he did not complete the deliverance of Israel from the hand of the Philistines.

Among modern scholars, Kaufman suggested that the editor wanted to stress the existence of two cycles in the Samson story. The first cycle describes Samson's heroic actions, which ends in chapter 15. The second one, which is found in chapter 16, contained descriptions of Samson's heroism but not in the battlefields. To express this idea, the editor used similar statements at the end of chapters 15 and $16 .{ }^{36}$ Budda, on the other hand, suggested that the Deuteronomist did not approve the traditions that are found in chapter 16 such as Samson going to a harlot, falling in a trap by Delilah and her people and the description of his death. Therefore, he removed those traditions and ended the story in 15:20. However, a later "liberal" editor inserted those rejected traditions back to the Samson story and ended it with a final note in 16:31. This was done without removing the previous ending of chapter $15 .{ }^{37}$ This suggestion by Budda removes the difficulties in the text. However, questions need to be asked. If this

\footnotetext{
34 Marc Zvi Brettler, The Book of Judges (London and New York: Routledge, 2002), 43.

35 J.T. Soțah 1.8; Numbers.R. 14.9.

36 Y. Kaufman, The Book of Judges (Jerusalem: Kiryat Sepher, 1978), 260.

37 Karl D. Budda, Das Buch Der Richter (Leipzig und Tübingen: Freiburg I.B, 1897), 91-2, 104; According to Boling chapter 16 is one of the seventh-century additions, see: Robert G. Boling, Judges (AB 6A; Garden City, New York: Doubleday, 1975), 136, 252-53.
} 
is the case, why did the Deuteronomist not remove the tradition about Jephthah the Gileadite who was a son of a harlot or the fact that he sacrificed his daughter? (Judg.11:1, 30-40)

It is strange that Samson is referred to as a judge. His deeds and actions show otherwise. He was a single hero who did not lead his people into a battle against a national enemy or oppressor. His battles are motivated by his personal agenda. At the end of his era, the land of Israel was not tranquil but was in a state of anarchy. His actions were temporary solutions to the battle against the Philistines. The anarchy that is described in the Book of Judges serves as a pretext to the Book of Samuel, which starts with the oppression of the Philistines. It was this anarchy and the oppression of the Philistines that ultimately led to the new era of the Israelite history; the inauguration of Saul as the first King of Israel.

\section{E CONCLUSION}

As a judge, Samson failed to carry out the mission that was assigned to him by God, and he brought destruction upon himself. His demise is described in minute details, which is not found with the other judges. The Philistine's jubilation of the capture of Samson is expressed by a short utterance with repeated rhythm. In the rhyme, the Philistine seranim attribute their victory to their god Dagon. The people repeated the rhyme chanted by the seranim and describe the destruction that was caused by Samson. The Philistines ended their rhyme with words displaying their confidence; that Samson would not be able to kill them anymore. In his prayer to God, Samson expressed his wish for death, which is different from his first prayer for victory. He ends his life in dramatic fashion, which resulted in the death of thousands of Philistines. Samson is the only one in the Hebrew Bible whose death wish is granted. Samson's desire to die has similarities to some of the fables from ancient times. Samson was buried by his family members, which shows that they respected him and were reconciled with him. They buried him between Zorah and Eshtaol at the tomb of his father Manoah. By mentioning the site of his burial, the story returns to the opening stage of our story. There it says that the spirit of God seized Samson between Zorah and Eshtaol.

\section{BIBLIOGRAPHY}

Amit, Yairah. The Book of Judges: The Art of Editing. Translated by Jonathan Chipman. Leiden: Brill, 1999.

Boling, Robert G. Judges. AB 6A; Garden City, New York: Doubleday, 1975.

Bartusch, Mark W. Understanding Dan. JSOT 379. Sheffield: Sheffield Academic Press, 2003.

Brettler, Marc Zvi. The Book of Judges. London and New York: Routledge, 2002.

Budda, Karl D. Das Buch Der Richter. Leipzig und Tübingen: Freiburg I.B, 1897. 
174 Bar, "The Death of Samson,” OTE 33/1 (2020): 162-174

Exum, J. Cheryl. "Theological Dimension of the Samson Saga." VT 33(1983):30-45. https://doi.org/10.1163/156853383X00323.

Gibbs, Laura, translator. Aesop's fable: A New Translation. Oxford: Oxford University Press, 2008.

Glendar, Shamai. "Samson is upon you." BethM 51(2006):63- 71.

Greenstein, Edward L. "Riddle of Samson." Proof 1(1981):237- 60.

Handy, L.K "Dagon" The Anchor Bible Dictionary. Edited by David Noel Freedman, 2:1-3. New York: Doubleday, 1992.

Healy, J.F. "Dagon," Dictionary of Deities and Demons in the Bible. Edited by Karel van der Toorn, Bob Becking, Pieter W. van der Horst, 216-19. Leiden: Brill, 1999.

Josephus, Flavius. Jewish Antiquities. Translated by H. St. J. Thackery. Cambridge, MA: Harvard University Press, 1930.

Kaufman, Y. The Book of Judges. Jerusalem: Kiryat Sepher, 1978.

Kim, Jichan. The Structure of the Samson Cycle. Kampen-The Netherlands: Kok Pharos Publishing House, 1993.

Malina, Bruce J and Jerome H. Neyrey, "Honor and Shame in Luke-Acts: Pivotal Values of the Mediterranean World." In the Social World of Luke -Acts, edited by Jerome H. Neyrey, 25-65. Peabody, Mass: Hendrickson, 1991.

Mobley, Gregory. The Empty Man. New York: Doubleday, 2005.

Moore, G.F. A Critical and Exegetical Commentary on Judges. New York: Charles Scribner's sons, 1895

Mazar, A. "A Philistine Temple at Tell Qasile." BA 36(1973):42-48. https://doi.org /10.2307/3211049.

Niditch, Susan. Judges: A Commentary. Louisville: Westminster John Knox, 2008.

Olson, D.T, "Judges,” In NIB 2:731-888. Nashville: Abingdon, 1988.

Olyan, Saul. "What Do Shaving Rites Accomplish and What Do They Signal in Biblical Ritual Contexts?" JBL 117(1998):611-22. https://doi.org/10.2307/3266630.

Van der Toorn. "Judges xvi 21 in the Light of Akkadian Sources." VT 36(1986):24853. https://doi.org/10.1163/156853386X00096.

Webb, Barry G. The Book of Judges. Grand Rapids, Michigan: William B. Eerdmans, 2012.

Zakovitz, Yair. The Life of Samson. Jerusalem: Magnes, 1982.

Shaul Bar, The University of Memphis, Bornblum Judaic Studies Program. E-mail: sbar@mempis.edu. ORCID: https://orcid.org/0000-0003-1186-1925. 